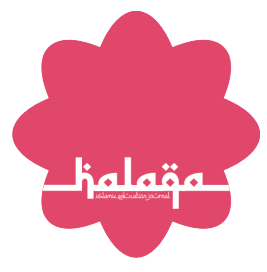

OPEN ACCESS ISSN 2503-5045 (online) ISSN 1412-9302 (print)

Edited by:

Musfiqon

Reviewed by:

Nurdyansyah

${ }^{*}$ Correspondence: Indra Martian Permana indramartian@gmail.com

Received: 28 Desember 2020

Accepted: 3 Januari 2021

Published: 25 Januari 2021

Citation:

Permana IM and Adam F (2020)

The Role of the Internet and Social

Media in the Spread of ISIS in

Indonesia.

Halaqa: Islamic Education Journal.

5:1.

doi: 10.21070/halaqa.v5vi1i.1130

\section{The Role of the Internet and Social Media in the Spread of ISIS in Indonesia}

\section{Peran Internet dan Media Sosial dalam Penyebaran ISIS di Indonesia}

\author{
Indra Martian Permana ${ }^{1 *}$, Fadzli Adam $^{2}$ \\ ${ }^{1}$ Sekolah Tinggi Agama Islam Perguruan Tinggi Dakwah Islam Indonesia (PTDII) Jakarta, Indonesia, ${ }^{2}$ University Sultan Zainal \\ Abidin (UniSZA), Malaysia
}

The Islamic State of Iraq and Syria (ISIS) is an organization against the background of Islamic jihad which was founded in Syria in 2014 and then brought the terror movement into war against those who disagreed with their movements including fighting Muslims in Syria. The advancement of Information Technology which gave birth to the internet and social media turned out to benefit ISIS, by spreading, recruiting, and raising funds through the internet and social media. ISIS distribution and propaganda can enter Indonesia through the internet and social media through the emergence of ISIS sites, Facebook ISIS and online bulletins and e-books online. This study aims to examine the dynamics of ISIS, especially in its recruitment on the internet. This research uses qualitative research methods. The conclusion of this study shows The impact is that not a few Indonesian citizens are interested and join ISIS and even go to Syria and fight with ISIS.

\footnotetext{
Keywords: ISIS, Internet, Social Media, ISIS Media
} 


\section{INTRODUCTION}

The development of information technology in the modern era presents products that make it easy for people to access and use it. Among the information technology products that currently play an important role in society are internet and social media technology. Today's internet and social media make it easy for humans to maximize their performance in all areas of life including business and economics with the birth of digital business, the field of teaching with the birth of e-learning and other fields. Arromadloni (2017); al Azhary (2016) Among those who maximize the development of information technology both the internet and social media are ISIS (Islamic State of Iraq and Syria) terrorist movements that were born from the jihadist movement in Sham. ISIS managed to make full use of the development of the internet and social media by spreading propaganda related to the success of ISIS in Sham applying Islamic sharia, leading Muslims with the existence of khilafah, using dinars and dirhams and so forth which were then spread to Muslims throughout the world so as to attract the sympathy of the people Islam throughout the world to join ISIS. And then we know all the propaganda is a lie. Steindal (2015); Adam (2016)

\section{METHOD}

This study implemented a qualitative method, namely research that aims to understand some of the strategies used by the ISIS group to clearly introduce the group to its open recruitment on social media as well as to analyze, describe, record and interpret the real situation that is happening Sugiyono (2019). Qualitative research is a research method based on the philosophy of postpositivism, used to examine the condition of natural objects where the researcher is the key instrument, the sampling of data sources is done purposively, the collection technique is by triangulation, the data analysis is inductive / qualitative, and the research results. qualitative emphasizes meaning more than generalization. Qualitative research rests on a natural background holistically, positions humans as a research tool, performs inductive data analysis, is more concerned with the process than the results and the results of the research carried out are agreed upon by the researcher and the research subject.

\section{RESULT AND DISCUSSION}

\section{ISIS in Indonesia}

Since the ISIS was declared in 2014 in Syria then ISIS spread its propaganda and understanding throughout the world including Indonesia. Indonesia is the target of spreading, recruiting and raising funds for ISIS terrorism activities in Syria in the name of Islamic jihad. There are no ISIS organizations in Indonesia but sympathizers and supporters who have a value and understanding with ISIS are many, such as the Jamaah Ansharut Tauhid (JAT), Jamaah Ansharut Tauhid (JAD) and the Jamaah Ansharu Khilafah (JAKI) [Interview with Irfan Idris, Deputy for Prevention of the National Counter Terrorism Agency (BNPT)]. There are those in the form of sympathizers, supporters, taking part in allegiance, and there are those who are truly involved in fighting with ISIS in Iraq and Syria. Kiram (2014)

ISIS in Indonesia was initially unpopular and received no sympathy because there was no central figure to bring ISIS in Indonesia, when Abu Bakar Ba'asyir who was serving his sentence at Nusakambangan prison for being involved in military training in Jantho, Aceh. Then it was influenced and provoked by Aman Abdurahman and Abu Yusuf who brought false news regarding ISIS which said ISIS was a jihadist movement that had implemented Islamic Sharia, enforced hudud, used dinars and dirhams, and established a Khilafah which then brought Abu Bakar Basasyir to pledge allegiance with $\mathrm{Al}$ Baghdis in ISIS leader [Interview with Ahmad Fatih, Spokesperson for Jamaah Ansharut Tauhid (JAT) who later left and joined the Ansharu Sharia Community for rejecting ISIS] Martian (2020). So after that the jihad movement and sympathizers of Abu Bakar Ba'asyir supported ISIS and pledged allegiance to ISIS in addition to ISIS propaganda in such a massive media.

[Figure 1 about here.]

\section{The Role of the Internet and Social Media in the Spread of ISIS in Indonesia}

The internet and social media have become the most effective tools in the modern and digital era in the spread of ISIS in Indonesia. The internet emerged as an important technological tool for Islamic radical groups in the process of spreading the news today. The use of the internet is used by ISIS to recruit new members, spread propaganda and as a way to communicate with different organizational cells Rahman and Adam (2017). In addition, the use of the internet and social media is also used to recruit sympathizers and new members and raise funds for the ISIS movement both in Syria and in Indonesian ISIS media. The use of the internet and media by ISIS in Indonesia includes media and propaganda that will influence public opinion, recruitment of ISIS members who will depart for Syria and fundraising for ISIS sympathizer. Hassan (2016)

\section{Media and Propaganda}

Gabriel Weimann found in 1998 on the internet there were only 12 terrorist group sites but in 2003 it increased to 2,650 terrorism group sites and in 2014 reached 9,800 sites Weimann (2016). In 2015 in Indonesia, the National Counterterrorism Agency (BNPT) asked the Ministry of Communication and Information (Kominfo) to close 22 radical sites even though only a few were recommended by the BNPT which indicated spreading radicalism and terrorism [Official website of Com- 
munication and Information, March 31, 2015]. Among the sites that spread the news and propaganda of ISIS were: 1) Millah Ibrahim, a media belonging to Aman Abdurahman, a terrorism convict who issued 500 news releases and writings every year to carry out propaganda [Interview with Sofyan Ats Tsuri, former convict of terrorism cases], 2) Al Mustaqbal, M.Fachri's media accused of terrorism cases died in prison 3) Media Facebook: Amaq News Agency 4) Online Bulletin: Fatihin online bulletin and online Bulletin Ink Al Busyro [Interview with Ardy Putra, BNPT Deputy Prevention Staff] Greene (2015)

[Figure 2 about here.]

\section{Recruitment}

ISIS media is used not only to do propaganda but one of its functions is to recruit Indonesian citizens who are interested in joining ISIS, then go to Syria and fight with ISIS. Indonesian citizens who were successfully recruited by ISIS to join and fight with ISIS reached 396 people and 81 of them were killed [Interview with Ardy Putra, BNPT Deputy Prevention Staff]. Among the media that actively preach and conduct ISIS propaganda in Syria as an effort to recruit ISIS members in Indonesia are Dabiq 14 Edition and Rumiyah magazines 11 Editions issued by Al Hayat Media Center which are translated into various Languages including Indonesian.

\section{REFERENCES}

Adam, F. (2016). Radical Religious Extremism Within The Context of Islamic Discussion. Man in India.

al Azhary, U. S. (2016). Islam Radikal: Telaah Kritis Radikalisme Dari Ikhwanul Muslimin Hingga ISIS (Abu Dhabi: Dar Al-Faqih), 1-204.

Arromadloni, M. N. (2017). Bid'ah Ideologi ISIS Catatan Penistaan ISIS Terhadap Hadits (Daulat Press).

Greene, K. J. (2015). ISIS: Trends in Terrorist Media and Propaganda. In International Studies Capstone Research Paper, 4-24-2015, Cedarville University, ed. and others (International Studies Capstone Research Paper), 1-56.

Hassan, A. S. A. (2016). DAESH : Kebangkitan dan Pengaruh Media Sosial. Jurnal Komunikasi Malaysian Journal of Communication Jilid 32, 381-404.

Kiram, I. M. (2014). ISIS Jihad atau Petualangan (Jakarta: Republika).

Martian, I. (2020). ISLAMIC STATE OF IRAQ AND SYRIA (ISIS) TERRORISM ACTION IN INDONESIA BETWEEN 2014-2018. International Journal of Islamic Studies and Social Sciences 2, 2-33.

Rahman, S. R. A. and Adam, F. (2017). ISIS: Peranan Internet Dan Media Sosial (INSPIRE: Proceeding of International Conference of Empowering Islamic Civ-
[Figure 3 about here.]

\section{Fundraising}

The next internet and social media is used by ISIS to collect and raise funds including providing assistance to ISIS families. BNPT released several organizations indicated to provide financial assistance to ISIS including: Infaq Dakwah Center, Aksi Cepat Tanggap, Hilal Ahmar Indonesia, Syam Organizer, Mer-c, Azzam Dakwah Center, Save the Children[1] . Although the parameters of the ISIS funding organization have not been clear from BNPT.

\section{CONCLUSION}

The development of information technology especially the internet and social media not only has a positive impact but also has a negative impact. Among the negative effects of the internet and social media is the widespread spread of ISIS terrorist thoughts and movements through the media. Indonesia is part of the impact of the spread of ISIS through the internet and social media. Restrictions and supervision of the internet and social media are the best solutions to counteract the movements and media propaganda carried out by ISIS.

ilization), 23-28.

Steindal, M. (2015). ISIS Totalitarian Ideology and Discourse An Analysis of The Dabiq Magazine Discourse (Norwegia: NMBU).

Sugiyono (2019). Metode Penelitian Kuantitatif Kualitatif dan R\&D (Bandung: Alfabeta), 1-464.

Weimann, G. (2016). Terror on the Internet: The New Arena, The New Challenges (Washington: United States Institute of Peace).

Conflict of Interest Statement: The authors declare that the research was conducted in the absence of any commercial or financial relationships that could be construed as a potential conflict of interest.

Copyright (c) 2020 Permana and Adam. This is an open-access article distributed under the terms of the Creative Commons Attribution License (CC BY). The use, distribution or reproduction in other forums is permitted, provided the original author(s) and the copyright owner(s) are credited and that the original publication in this journal is cited, in accordance with accepted academic practice. No use, distribution or reproduction is permitted which does not comply with these terms. 


\section{LIST OF FIGURES}

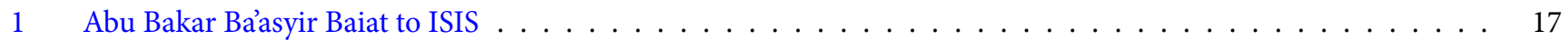

2 MillahIbrahim , ISIS Media . . . . . . . . . . . . . . . . . . . . . . . . 18

3 Dabiq, ISIS magazine that conducts propaganda and recruitment . . . . . . . . . . . . . . . . . 19 


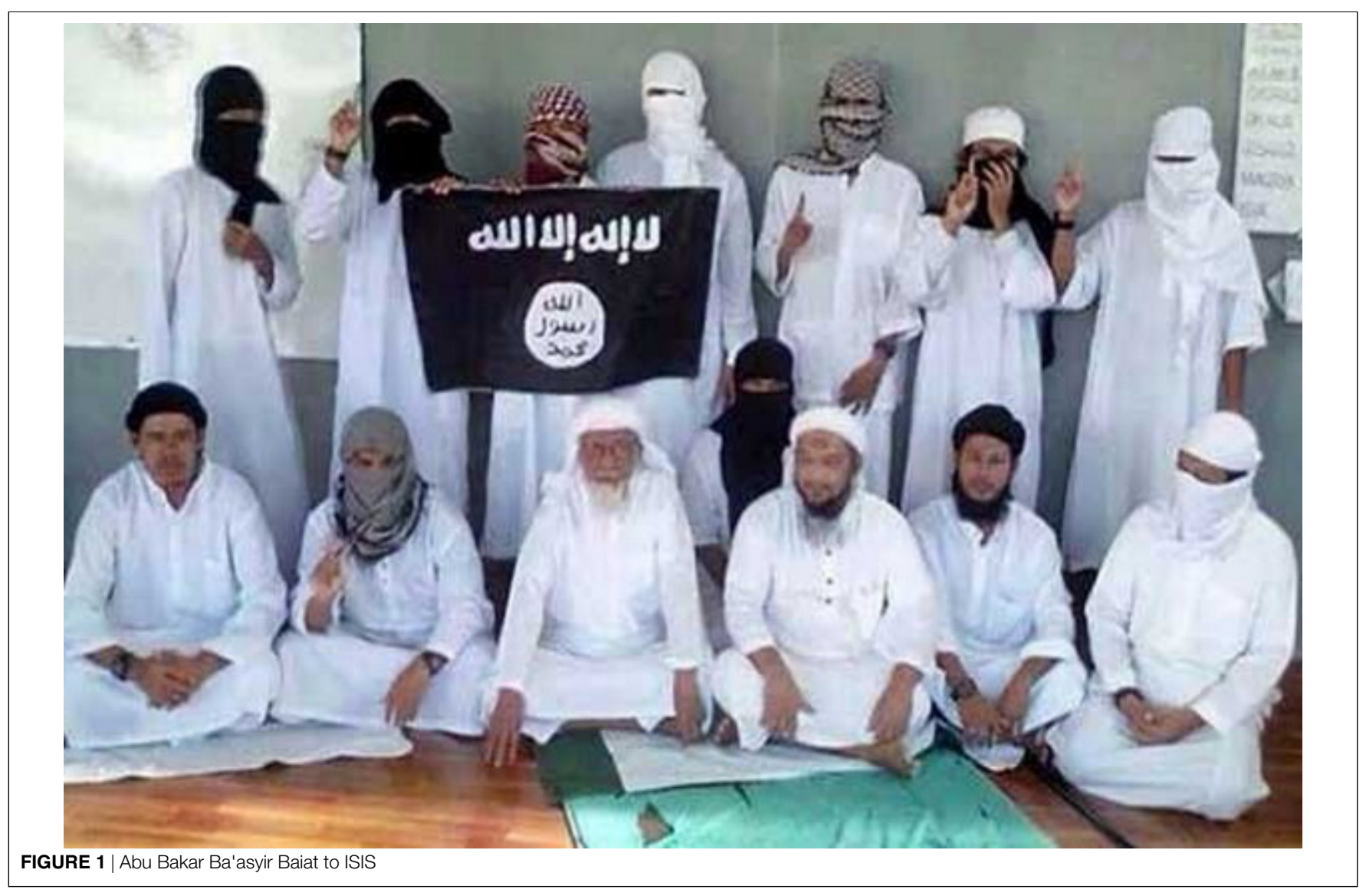


FIGURE 2 | Millahlbrahim , ISIS Media

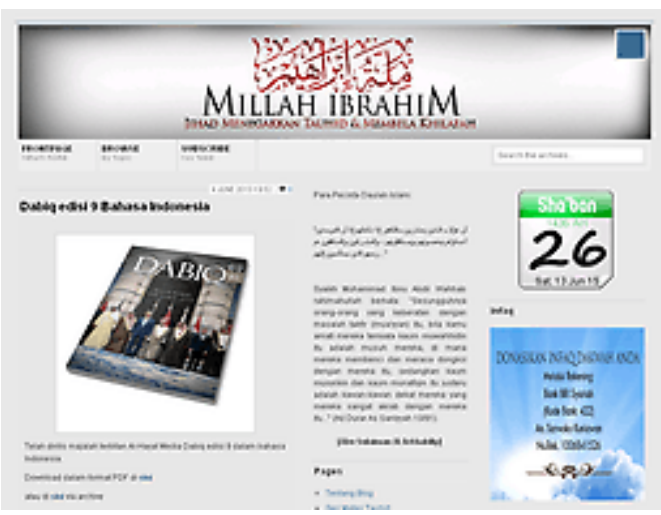




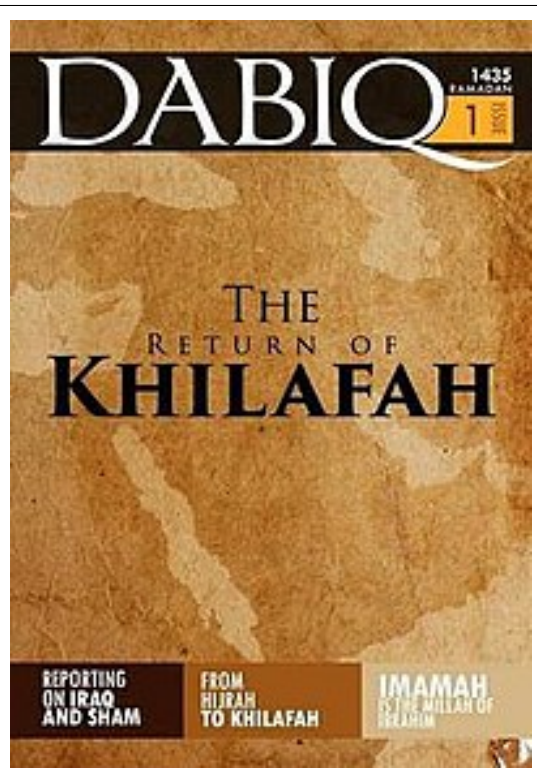

FIGURE 3 | Dabiq, ISIS magazine that conducts propaganda and recruitment 